\title{
Fermentation of mandelate to benzoate and acetate by a homoacetogenic bacterium
}

\author{
Christina Dörner and Bernhard Schink \\ Lehrstuhl Mikrobiologie I der Eberhard-Karls-Universität, Auf der Morgenstelle 28, W-7400 Tübingen, Federal Republic of Germany
}

Received February 14, 1991/Accepted May 31, 1991

\begin{abstract}
A strictly anaerobic, Gram-positive, rodshaped bacterium, strain AmMan1, was isolated from freshwater sediment with mandelate ( $\alpha$-hydroxyphenylacetate) as sole carbon and energy source, and was assigned to the genus Acetobacterium. Only the Denantiomer of mandelate was degraded, and was fermented to acetate and benzoate. Non-aromatic growth substrates (pyruvate, lactate, malate, glycerol, ethylene glycol, and $\mathrm{H}_{2} / \mathrm{CO}_{2}$ ) were fermented to acetate as sole product. Methoxylated aromatics were demethoxylated to the corresponding phenols. The guanine-plus-cytosine content of the DNA was $36.5 \pm 1.5 \%$. Carbon monoxide dehydrogenase, dichlorophenol indophenol-reducing lactate dehydrogenase, NAD-dependent mandelate dehydrogenase, phosphate acetyl transferase, acetate kinase, and pyruvate- or phenylglyoxylate-dependent benzylviologen reductase were measured in mandelateand/or lactate-grown cells, respectively. A pathway of the homoacetogenic fermentation of mandelate is suggested as another example of incomplete substrate oxidation by homoacetogenic bacteria.
\end{abstract}

Key words: Anaerobic degradation - Mandelate - Lactate - Homoacetogenic fermentation - Mandelate dehydrogenase - Phenylglyoxylate benzylviologen oxidoreductase

Mandelic acid is a common constituent of plant tissues such as wheat leaves and grapes (Fewson 1988). Amygdalin, a glycoside of almonds, is the $\beta$-gentiobioside of Dmandelonitrile (Conn 1981). Aerobic mandelate degradation has been studied in detail with $P$ seudomonas putida (Gunsalus et al. 1953a; Stanier et al. 1953; Gunsalus et al. $1953 \mathrm{~b}$ ). These investigations introduced the concept of "simultaneous induction" as a strategy to elucidate biochemical pathways, and formulation of the "mandel- ate pathway " of degradation of aromatic compounds. Anaerobic degradation of mandelate has not been studied so far. Recently several nitrate-reducing Pseudomonas strains were described which were isolated with phenylacetate, 4-hydroxyphenylacetate, or salicylate; these strains oxidized also 4-hydroxymandelate to $\mathrm{CO}_{2}$ in the absence of $\mathrm{O}_{2}$ with nitrate as electron acceptor (Seyfried 1989). In the present study, fermenting bacteria are described which catalyze an oxidation of mandelate to benzoate.

\section{Materials and methods}

\section{Sources of organisms}

Strain AmMan1 was isolated from black, anoxic sediment of the Ammerkanal, a creek near Tübingen, Germany.

\section{Medium}

The medium used was sulfide-reduced and buffered with $30 \mathrm{mM}$ $\mathrm{NaHCO}_{3}$ (Widdel and Pfennig 1981). It contained 7-vitamin solution (Widdel and Pfennig 1981), selenite-tungstate solution (Tschech and Pfennig 1984) and the trace element solution SL 10 (Widdel et al. 1983). The final $\mathrm{pH}$ of the medium was adjusted to 7.2-7.4. The growth temperature was $28^{\circ} \mathrm{C}-30^{\circ} \mathrm{C}$.

\section{Isolation and characterization}

A pure culture was obtained by applying the agar shake culture method (Pfennig 1978). Purity was checked microscopically and by growth tests in complex medium (AC medium, Difco Laboratories, Detroit, Mich., USA) with or without $10 \mathrm{mM}$ DL-mandelate added. Gram staining was carried out according to Bartholomew (1962). The DNA base composition was determined by the thermal denaturation method according to De Ley (1970) after extraction according to Marmur (1961). Escherichia coli K12 was taken as reference. Substrate utilization was tested in $22 \mathrm{ml}$ screw-cap tubes in two parallels for each substrate. Substrates were added from neutralized and filter-sterilized stock solutions. Utilization of $\mathrm{H}_{2}$ was tested in $20 \mathrm{ml}$ Hungate tubes sealed with butyl rubber septa 
and containing $10 \mathrm{ml}$ of inoculated basal medium under an atmosphere of $90 \% \mathrm{H}_{2} / 10 \% \mathrm{CO}_{2}$. Optical densities were measured directly in a Bausch and Lomb spectronic 20 spectrophotometer (Milton Roy, Rochester, N.Y., USA) in $22 \mathrm{ml}$ screw-cap tubes. Cell dry matter was calculated from turbidity at $578 \mathrm{~nm}$ using the conversion factor $0.1 \mathrm{OD}_{578}=20 \mathrm{mg}$ dry matter per liter, which was obtained by direct gravimetric determinations in $1000 \mathrm{ml}$ cultures grown with mandelate.

\section{Spectrophotometric determinations}

UV-absorption spectra $(200-350 \mathrm{~nm})$ of aromatic compounds were recorded using an Uvikon 860 spectrophotometer (Kontron, Zürich, Switzerland).

\section{Analytical determinations}

Acetate was determined by gas chromatography as previously described (Platen and Schink 1987). Benzoate and mandelate were determined by high pressure liquid chromatography (HPLC) with a Beckman System Gold system equipped with a UV detector at 210 and $230 \mathrm{~nm}$ wavelength on a reversed phase $\left(\mathrm{C}_{18}\right.$ column (Merck chromosorb, length $12.5 \mathrm{~cm}$, inner diameter $4 \mathrm{~mm}$, particle diameter $5 \mu \mathrm{m})$. The mobile phase was a mixture of $50 \%$ ammonium phosphate buffer, $\mathrm{pH} 2.6$, and $50 \%$ methanol $(1 \mathrm{ml} / \mathrm{min})$. Sulfide formation from sulfate, sulfite, thiosulfate, or sulfur was analysed by a rapid detection test (Cord-Ruwisch 1985). Formation of nitrite from nitrate was determined according to Procházková (1959). Protein was quantified according to Bradford (1970) using bovine serum albumin as reference.

\section{Induction experiments}

Induction experiments were carried out with anaerobically prepared cell suspensions $\left(\mathrm{OD}_{578}=3\right.$ ) of strain AmMan1. $5 \mathrm{ml}$ cell suspension was incubated anaerobically with $10 \mathrm{mM}$ lactate or $10 \mathrm{mM}$ mandelate. Parallel assays with chloramphenicol $(30 \mathrm{mg} / \mathrm{l})$ served as controls. Acetate production was followed over $1-25 \mathrm{~h}$.

\section{Preparation of cell extracts}

Cells were grown in $100 \mathrm{ml}$ infusion bottles to the late exponential phase and centrifuged in the culture vessel under $\mathrm{N}_{2}$ atmosphere $\left(4000 \times g, 40 \mathrm{~min}, 4^{\circ} \mathrm{C}\right)$. They were washed once in $50 \mathrm{mM}$ anoxic potassium phosphate buffer, $\mathrm{pH} 7.0$, and resuspended in $3 \mathrm{ml}$ of the same buffer. Cells were disrupted in a $\mathrm{N}_{2}$-flushed French pressure cell at $138 \mathrm{MPa}$. After microscopic control, cell debris was removed by centrifugation at $5000 \times g$ for $20 \mathrm{~min}$. The crude extract was used directly for enzymatic studies.

\section{Enzyme assays}

All assays were performed with crude cell extracts of mandelate or lactate-grown cells under anaerobic conditions at $25^{\circ} \mathrm{C}$. Phosphate acetyl transferase was measured with intact cells permeabilized with $\mathrm{N}$, Cetyl-N,N,N,-trimethyl ammoniumbromide (CTAB). All additions were made anoxically and injected into the nitrogen-gassed and rubber-sealed cuvettes with microliter syringes. Activities were measured photometrically in a Hitachi $1000-40$ spectrophotometer (Hitachi, Tokyo, Japan). Phosphate acetyl transferase and acetate kinase were measured by standard methods (Bergmeyer 1974). Mandelate dehydrogenase was measured with NADH and phenylglyoxylate according to a test described for lactate dehydrogenase

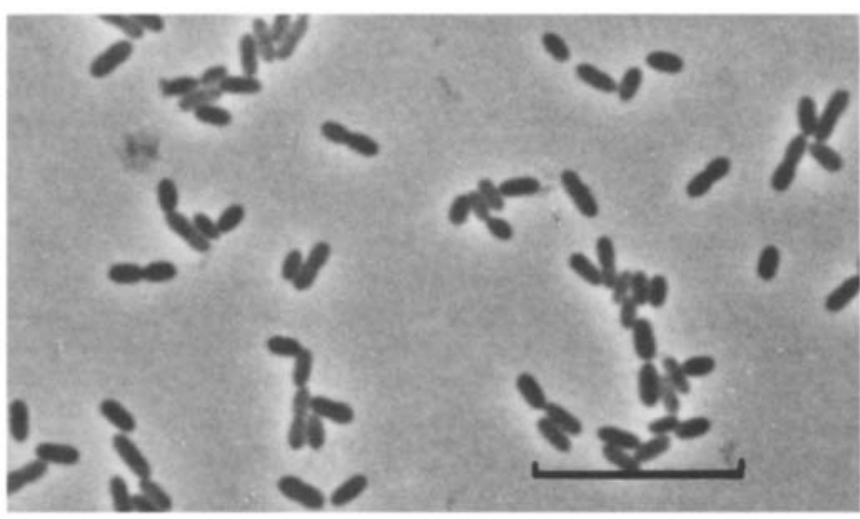

Fig. 1. Phase contrast photomicrograph of strain AmMan1. Bar equais $10 \mu \mathrm{m}$

(Bergmeyer 1974). Lactate dehydrogenase activity was determined with dichlorophenol indophenol as artificial electron acceptor (Molinari and Lara 1960). Pyruvate:acceptor oxidoreductase and phenylglyoxylate: acceptor oxidoreductase were measured with benzyl viologen as electron acceptor (modified after Odom and Peck 1981). Benzoyl-CoA:acetate CoA transferase was measured in a coupled enzyme assay using benzoyl-CoA and acetate as substrates (modified after Hilpert et al. 1984).

\section{Chemicals}

All chemicals were of reagent grade quality and obtained from Fluka, Neu-Ulm; Merck, Darmstadt; Sigma, Deisenhofen, and Boehringer, Mannheim, FRG. Gases were obtained from MesserGriesheim, Darmstadt, FRG.

\section{Results}

\section{Enrichment and isolation}

Enrichment cultures with $50 \mathrm{ml}$ of freshwater or saltwater medium containing $10 \mathrm{mM}$ DL-mandelate were inoculated with about $5 \mathrm{ml}$ of anoxic mud from various freshwater and marine habitats. Gas production started after 5-7 days. After two weeks of incubation, first transfers were made with $10 \%$ inoculum. Similar bacterial cells developed in all enrichment series. After 5 transfers, the enrichment culture from the Ammerkanal contained almost exclusively one type of rod-shaped motile bacteria. This enrichment culture was subjected to agar shake dilution series. Yellow, lens-shaped colonies developed after 6 days of incubation, and a pure culture of strain AmMan1 was obtained after a subsequent second agar dilution.

\section{Morphology}

Cells of strain AmMan1 were straight rods with rounded ends, measuring $1 \times 1.5-3 \mu \mathrm{m}$ (Fig. 1). They occurred singly or in pairs, seldom in short chains. Cells were motile in the early logarithmic growth phase, but lost motility in ageing cultures. Cells stained Gram-positive 


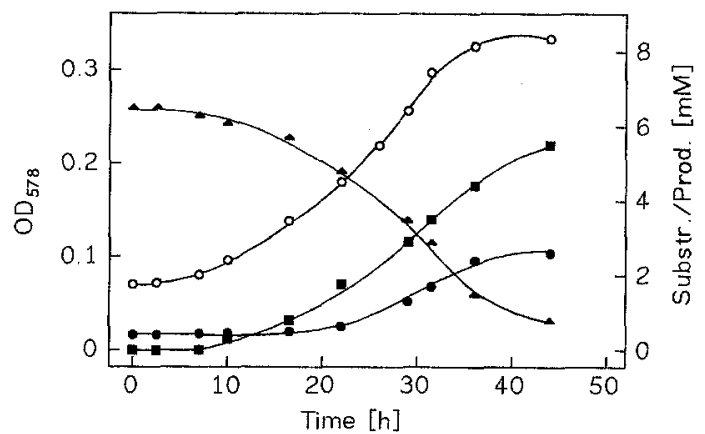

Fig. 2. Fermentation time course of strain AmMan1 in mineral medium with D-mandelate as substrate. $\mathrm{OD}_{578}$ : optical density at $578 \mathrm{~nm}$. Symbols: $\bigcirc$ cell density; $\boldsymbol{\Delta}$ mandelate; $\boldsymbol{\square}$ benzoate; - acetate

and behaved Gram-positive also in the $\mathrm{KOH}$-test (Gregersen 1978). Spores were never detected. The guanine-plus-cytosine content of the DNA was $36.5 \pm 1.5$ mol $\%$. No cytochromes were detected by redox difference spectroscopy in crude cell extracts.

\section{Physiology}

Strain AmMan1 grew only under strictly anaerobic conditions in freshwater medium. The $\mathrm{pH}$ range was $5.9-$ 8.0 with an optimum at $\mathrm{pH} 7.2$. The temperature range was $4^{\circ} \mathrm{C}$ to $32^{\circ} \mathrm{C}$; optimal growth occurred at $28^{\circ} \mathrm{C}-$ $30^{\circ} \mathrm{C}$ with a doubling time of $17 \mathrm{~h}$ (Fig. 2). The new isolate tolerated $\mathrm{NaCl}$ concentrations up to $10 \mathrm{~g} / 1$ and was not inhibited by phosphate concentrations up to $50 \mathrm{mM}$. D-mandelate was fermented to benzoate and acetate, and lactate, malate, pyruvate, glycerol, ethylene glycol, and $\mathrm{H}_{2} / \mathrm{CO}_{2}$ to acetate as sole product (Table 1).

Methoxylated aromatic compounds such as vanillate, trimethoxybenzoate, trimethoxycinnamate, syringate, and ferulate, were demethylated to the respective hydroxy derivatives plus acetate. Acetate was determined quantitatively, whereas the degradation products of the aromatic compounds were determined only qualitatively by UV-spectroscopy. The fermentation stoichiometry and growth yields are documented in Table 1 . The following substrates were not degraded by strain AmMan1: Glucose, arabinose, xylose, saccharose, lactose, fumarate, succinate, aspartate, formate, methanol, ethanol, propanol, 2-hydroxybutyrate, 3-hydroxybutyrate, 4-hydroxybutyrate, phenylacetate, salicylate, methoxyacetate, dimethoxyethane, diethoxyethane, methoxyethanol, ethoxyethanol, triethylene glycol. No inorganic electron acceptors such as nitrate, nitrite, sulfate, sulfite, thiosulfate, or sulfur were reduced.

\section{Enzyme activities}

Enzymes were assayed in French press cell extracts or in suspensions of DL-mandelate or L-lactate grown cells of strain AmMan1 permeabilized with CTAB. NAD-independent L-lactate dehydrogenase, pyruvate:acceptor oxidoreductase, phenylglyoxylate:acceptor oxidoreductase, phosphate acetyl transferase, and acetate kinase were measured at sufficient activities, both in mandelate and lactate grown cells. NAD-dependent D-mandelate dehydrogenase activity could only be detected in mandelate-grown cells. A benzoyl-CoA acetate CoA transferase activity was not found. Carbon monoxide dehydrogenase was present at high activities in mandelate-grown cells. The results of enzyme measurements are summarized in Table 2.

\section{Induction experiments}

Enzyme determinations revealed that two different enzyme systems were involved in the initial steps of mandelate and lactate degradation by strain AmMan1. Induction experiments were carried out to get additional information whether both systems were constitutive or inducible. Lactate degradation started immediately with lactate- and mandelate-grown cells, whereas mandelate was degraded by lactate-grown cells with a delay of $6 \mathrm{~h}$ (results not shown). In the presence of chloramphenicol, lactate-grown cells did not start mandelate oxidation during $25 \mathrm{~h}$ of incubation.

\section{Discussion}

The new bacterial strain described in this communication, strain AmMan1, was enriched and isolated with mandel-

Table 1. Fermentation stoichiometries and growth yields of strain AmMan1

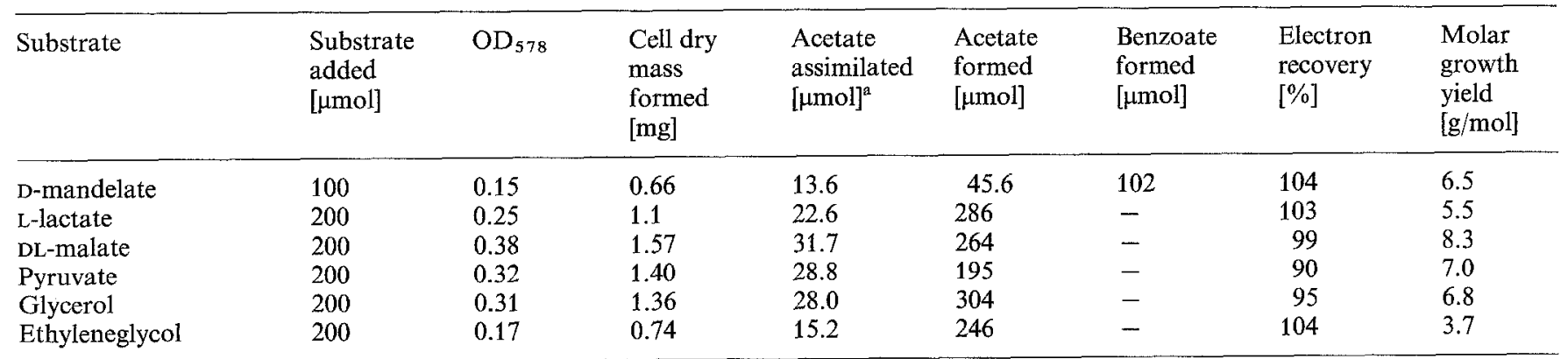

a Acetate assimilated was calculated using the formula $\left(\mathrm{C}_{4} \mathrm{H}_{7} \mathrm{O}_{3}\right)$ for cell material 
Table 2. Specific activities of enzymes (in $\mu \mathrm{mol} \times \min ^{-1} \times \mathrm{mg}$ protein $^{-1}$ ) detected in crude cell extracts of cells of strain AmMan1 grown with mandelate or lactate

\begin{tabular}{|c|c|c|c|}
\hline Enzyme & $\begin{array}{l}\mathrm{EC} \\
\text { number }^{\mathrm{a}}\end{array}$ & $\begin{array}{l}\text { Specific } \\
\text { activity } \\
\text { in man- } \\
\text { delate- } \\
\text { grown cells }\end{array}$ & $\begin{array}{l}\text { Specific } \\
\text { activity in } \\
\text { lactate- } \\
\text { grown } \\
\text { cells }\end{array}$ \\
\hline $\begin{array}{l}\text { CO-dehydrogenase } \\
\text { Mandelate dehydro- } \\
\text { genase }\end{array}$ & 1.2 .99 .2 & 2.1 & n.d. ${ }^{b}$ \\
\hline $\begin{array}{l}\text { NAD-dependent } \\
\text { Mandelate dehydro- } \\
\text { genase }\end{array}$ & - & 4.0 & 0 \\
\hline $\begin{array}{l}\text { NAD-independent } \\
\text { Lactate dehydrogenase }\end{array}$ & - & 0.02 & 0 \\
\hline $\begin{array}{l}\text { NAD-dependent } \\
\text { Lactate dehydrogenase }\end{array}$ & 1.1.1.27 & 0 & 0 \\
\hline $\begin{array}{l}\text { NAD-independent } \\
\text { Pyruvate:acceptor }\end{array}$ & 1.1.2.3 & 0.26 & 0.2 \\
\hline $\begin{array}{l}\text { oxidoreductase } \\
\text { Phenylglyoxylate: } \\
\text { acceptor }\end{array}$ & 1.2.7.1 & 2.8 & 2.6 \\
\hline oxidoreductase & $1.2 .7 .-$ & 4.7 & 0.4 \\
\hline $\begin{array}{l}\text { Phosphate acetyl } \\
\text { transferase }^{c}\end{array}$ & 2.3.1.8 & 0.9 & 1.6 \\
\hline $\begin{array}{l}\text { Acetate kinase } \\
\text { BenzoylCoA-acetate: }\end{array}$ & 2.7 .2 .1 & 1.7 & n.d. \\
\hline CoA transferase & - & 0 & 0 \\
\hline
\end{tabular}

a According to International Union of Biochemistry (1984)

b Not determined

- Phosphate acetyl transferase was determined in intact cells permeabilized with CTAB

ate as sole source of energy and carbon. D-mandelate was degraded according to the following fermentation equation:

2 D-mandelate $^{-} \rightarrow 2$ benzoate $^{-}+$acetate $^{-}+\mathrm{H}^{+}$.

Methoxylated aromatic compounds were incompletely oxidized as well to the respective phenols plus acetate, a fermentation process similar to that originally described for Acetobacterium woodii (Bache and Pfennig 1981). Acetate was the only fermentation product of growth with lactate, malate, or pyruvate. The new isolate was able to grow autotrophically with $\mathrm{H}_{2}$ and $\mathrm{CO}_{2}$, and carbon monoxide dehydrogenase was found at high activities. The guanine-plus-cytosine content of the DNA of strain AmMan1 was determined to be $36.5 \pm 1.5 \%$. These properties, together with the characteristic cell shape and motility, allow to affiliate strain AmMan1 with the genus Acetobacterium (Schink and Bomar 1991). From its substrate utilization pattern, strain AmMan1 resembles most A. malicum by its capacity to grow with malate, and its inability to utilize formate or methanol. However, $A$. malicum does not grow with mandelate.

Mandelate degradation according to Eq. (1) resembles homoacetogenic lactate degradation:

2 lactate $^{-} \rightarrow 2$ acetate $^{-}+$acetate $^{-}+\mathrm{H}^{+}$

$\Delta \mathrm{G}^{\circ \prime}=-53.7 \mathrm{~kJ} / \mathrm{mol}$ lactate (Thauer et al. 1977).

This is not surprising since mandelate differs from lactate
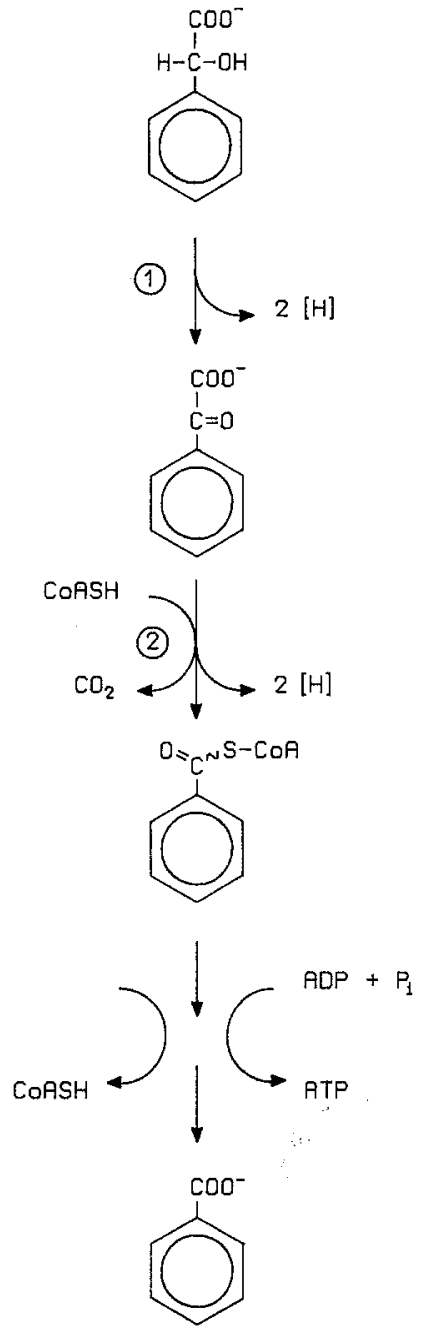

Fig. 3. Proposed pathway for mandelate degradation by strain AmMan1. Numbers in circles refer to the following enzymes which were detected in cell-free extracts: 1 = Mandelate dehydrogenase, 2 = Phenylglyoxylate:acceptor oxidoreductase. Whether ATP synthesis proceeds directly via benzoyl $\mathrm{CoA}$ and benzoyl phosphate or after CoA transfer to acetate could not be decided on the basis of our experiments

only by the substituent (phenyl versus methyl) attached to carbon atom 2 . Also enzymatic studies in cell-free extracts revealed that the pathway of mandelate degradation closely resembled that of lactate degradation. Both pathways were initiated by a dehydrogenase reaction. Mandelate dehydrogenase coupled with NAD, whereas lactate dehydrogenase activity could be measured only with dichlorophenol indophenol as electron acceptor. Only a D-mandelate dehydrogenase was found in cell extract of strain AmMan1; L-mandelate was not metabolized. Mandelate dehydrogenase was found only in mandelate-grown cells at high activity ( $4 \mathrm{U}$ per $\mathrm{mg}$ protein), while lactate dehydrogenase was constitutive and activities were comparably low $(0.2-0.26 \mathrm{U}$ per $\mathrm{mg}$ protein), perhaps due to oxygen influence during cell preparation. The membrane-bound lactate dehydrogenase of Desulfovibrio vulgaris is known to be extremely oxygen-sensitive (Stams and Hansen 1982). Phenylglyoxylate- and pyruvate : acceptor oxidoreductase were 
measured with benzylviologen as electron acceptor, and were both present after growth with either substrate. The physiological acceptor is probably ferredoxin which is present in homoacetogenic bacteria (Diekert 1991). Since growth yields with mandelate were equal to those with lactate it is obvious that phenylglyoxylate oxidation forms primarily an energy-rich compound such as benzoylCoA. Unfortunately, a benzoylCoA:acetate CoA transferase could not be detected. Because phosphate acetyl transferase and acetate kinase are constitutive enzymes in homoacetogenic metabolism it remains unclear whether ATP is synthesized from benzoylCoA and benzoyl phosphate directly, or after CoA transfer to acetate. The pathway of mandelate degradation by strain AmMan1 is depicted in Fig. 3; it characterizes mandelate degradation as another incomplete oxidation process typical of homoacetogenic bacteria.

\section{References}

Bache R, Pfennig N (1981) Selective isolation of Acetobacterium woodii on methoxylated aromatic acids and determination of growth yields. Arch Microbiol 130:255-261

Bartholomew JW (1962) Variables influencing results and the precise definition of steps in gram staining as a means of standardizing the results obtained. Stain Technol 37:139-155

Bergmeyer HU (1974) Methoden der enzymatischen Analyse, 3rd edn. Verlag Chemie, Weinheim

Bradford MM (1970) A rapid and sensitive method for the quantitation of microgram quantities of protein utilizing the principle of protein-dye binding. Anal Biochem 72:248-254

Conn EE (1981) Cyanogenic glycosides. In: Stumpf PK, Conn EE (eds) The biochemistry of plants. Academic Press, New York, pp $479-500$

Cord-Ruwisch R (1985) A quick method for the determination of dissolved and precipitated sulfides in cultures of sulfate-reducing bacteria. J Microbiol Methods 4:33-36

De Ley J (1970) Reexamination of the association between melting point, buoyant density, and the chemical base composition of deoxyribonucleic acid. J Bacteriol 101:738-754

Diekert G (1991) The acetogenic bacteria. In: Balows A, Trüper HG, Dworkin M, Harder W, Schleifer KH (eds) The prokaryotes, 2nd edn. Springer, Heidelberg New York (in press)

Fewson CA (1988) Microbial metabolism of mandelate: a microcosm of diversity. FEMS Microbiol Rev 54:85-110

Gregersen T (1978) A rapid method for distinction of Gram-negative from Gram-positive bacteria. Eur J Appl Microbiol Biotechnol $5: 123-127$
Gunsalus CF, Stanier RY, Gunsalus IC (1953a) The enzymatic conversion of mandelic acid to benzoic acid. III. Fractionation and properties of the soluble enzymes. J Bacteriol 66:548-553

Gunsalus IC, Gunsalus CF, Stanier RY (1953b) The enzymatic conversion of mandelic acid to benzoic acid. 1. Gross fractionation of the system into soluble and particulate components. $J$ Bacteriol 66:538-542

Hilpert W, Schink B, Dimroth P (1984) Life by a new decarboxylation-dependent energy conservation mechanism with $\mathrm{Na}^{+}$as coupling ion. EMBO J 3:1665-1670

Marmur J (1961) A procedure for the isolation of deoxyribonucleic acid from microorganisms. J Mol Biol 3:208-218

Molinari R, Lara FJS (1960) The lactic dehydrogenase of Propionibacterium pentosaceum. Biochem J 75:57-65

Odom JM, Peck HD (1981) Localization of dehydrogenases, reductases, and electron transfer components in the sulfate-reducing bacterium Desulfovibrio gigas. J Bacteriol 149:136-141

Pfennig N (1978) Rhodocyclus purpureus gen. nov. and sp. nov., a ring shaped, vitamin $\mathrm{B}_{12}$-requiring member of the family Rhodospirillaceae. Int J Syst Bacteriol 28:283-288

Platen H, Schink B (1987) Methanogenic degradation of acetone by an enrichment culture. Arch Microbiol 149:136-141

Procházková L (1959) Bestimmung der Nitrate im Wasser. Z Anal Chem 167:254-260

Schink B, Bomar M (1991) The Genera Acetobacterium, Acetogenium, Acetoanaerobium, and Acetitomaculum. In: Ballows A, Trüper HG, Dworkin M, Harder W, Schleifer Kh (eds) The prokaryotes, $2^{\text {nd }}$ edn. Springer, Heidelberg New York (in press)

Seyfried B (1989) Anaerober Abbau von Phenylacetat über $\alpha$-Oxidation durch denitrifizierende Pseudomonas-Arten. PhD-Thesis, Ulm

Stams AJM, Hansen TA (1982) Oxygen labile L $(+)$ lactate dehydrogenase activity in Desulfovibrio desulfuricans. FEMS Microbiol Lett 13:389-394

Stanier RY, Gunsalus IC, Gunsalus CF (1953) The enzymatic conversion of mandelic acid to benzoic acid. II. Properties of the particulate fractions. J Bacteriol 66:543-547

Thauer RK, Jungermann K, Decker K (1977) Energy conservation in chemotrophic anaerobic bacteria. Bacteriol Rev 41:100180

Tschech A, Pfennig N (1984) Growth yield increase linked to caffeate reduction in Acetobacterium woodii. Arch Microbiol 137:163-167

Widdel F, Pfennig N (1981) Studies on dissimilatory sulfate-reducing bacteria that decompose fatty acids. I. Isolation of a new sulfate-reducer enriched with acetate from saline environments. Description of Desulfobacter postgatei gen. nov. sp. nov. Arch Microbiol 129:395-400

Widdel F, Kohring GW, Mayer F (1983) Studies on dissimilatory sulfate-reducing bacteria that decompose fatty acids. III. Characterization of the filamentous gliding Desulfonema limicola gen. nov. sp. nov., and Desulfonema magnum sp. nov. Arch Microbiol 134:286-294 